\title{
Aeromicrobium halocynthiae sp. nov., a taurocholic acid-producing bacterium isolated from the marine ascidian Halocynthia roretzi
}

Correspondence Hak Cheol Kwon hkwon@kist.re.kr

\author{
Sung Hun Kim, ${ }^{1,2}$ Hyun Ok Yang, ${ }^{1}$ Young Chang Sohn ${ }^{2}$ \\ and Hak Cheol Kwon ${ }^{1}$
}

\author{
${ }^{1}$ Korea Institute of Science and Technology, Gangneung, Gangwondo, 210-340, Republic of Korea \\ ${ }^{2}$ Division of Applied Marine Biotechnology and Engineering, Faculty of Marine Bioscience and \\ Technology, Gangneung-Wonju National University, Gangneung, 210-702, Republic of Korea
}

In an effort to investigate the chemical potential of microbes growing in marine environments, the microbial diversity associated with marine invertebrates and the production of secondary metabolites was investigated. During this survey, a new bile acid-producing, Grampositive bacterium was isolated from the ascidian Halocynthia roretzi. NCBI nucleotide BLAST searches using the 16S rRNA gene sequence of the cultured bacterium revealed that the new isolate shared a close phylogenetic affiliation with members of the genus Aeromicrobium. It was most closely related to Aeromicrobium ginsengisoli with 16S rRNA gene sequence similarities of $97.7 \%$.

\footnotetext{
Abbreviation: SEM, scanning electron microscope.
}

The GenBank/EMBL/DDBJ accession number for the 16S rRNA gene sequence of strain KME $001^{\top}$ is FJ042789.

A table detailing the fatty acid contents of strain $\mathrm{KME} 001^{\top}$ and related species of the genus Aeromicrobium is available with the online version of this paper. Supplementary figures showing HPLC/MS, ${ }^{1} \mathrm{H}-\mathrm{NMR},{ }^{13} \mathrm{C}-$ NMR spectra and a TLC chromatogram of the secondary metabolites of strain $\mathrm{KME} 001^{\top}$ are also available.
The genus Aeromicrobium, first proposed by Miller et al. (1991), belongs to the family Nocardioidaceae within the order Actinomycetales. Currently, nine recognized species of the genus Aeromicrobium have been reported including Aeromicrobium erythreum (Miller et al., 1991), A. fastidiosum (Tamura \& Yokota, 1994), A. alkaliterrae (Yoon et al., 2005), A. panaciterrae (Cui et al., 2007) and A. ginsengisoli (Kim et al., 2008) from soil, A. marinum (Bruns et al., 2003), A. tamlense (Lee \& Kim, 2007) and A. ponti (Lee \& Lee, 2008) from the marine environment, and A. flavum (Tang et al., 2008) from air. Erythromycin is a representative secondary metabolite produced by A. erythreum (Miller et al., 1991). However, apart from erythromycin, no biologically valuable organic compounds have been reported from members of the genus Aeromicrobium.

The search for bioactive secondary metabolites in the culture broth of strain $\mathrm{KME} 001^{\mathrm{T}}$ led to the isolation of taurocholic acid, a major secondary metabolite of this bacterium. Cholic acid is a bile acid produced by 
mammalian liver cells. The acid is synthesized in the liver from cholesterol and is generally found in a conjugated form with taurine and glycine. Taurocholic acid, taurineconjugated cholic acid and its sodium salt have been used as cholagogues (agents which promote the flow of bile) and these compounds are currently manufactured commercially by purification from animal bile (Dewick, 2001). Currently, only 10 bacterial strains have been reported as bile acid-producing prokaryotes. Bile acids produced by these strains include cholic acid, deoxycholic acid, glycocholic acid, glycodeoxycholic acid and cholic acid methyl ester (Park et al., 1995; Maneerat et al., 2005; Kim et al., 2007). To date, a taurocholic acid-producing bacterium has not been reported.

This paper describes the characterization of strain KME $001^{\mathrm{T}}$ by means of a polyphasic taxonomic approach.

Strain KME $001^{\mathrm{T}}$ was isolated from a marine ascidian, Halocynthia roretzi, collected at a depth of $15 \mathrm{~m}$ (water temperature: $\left.17{ }^{\circ} \mathrm{C}\right)$ near Kyung-Po beach, Korea (37 $48^{\prime}$ $36.33^{\prime \prime} \mathrm{N}, 128^{\circ} 54^{\prime} 46.19^{\prime \prime} \mathrm{E}$ ), in June 2007. As soon as the ascidian was collected, it was washed with autoclaved seawater. The incurrent and excurrent siphon tissues were ground and diluted with autoclaved seawater (ratio of ground tissue to seawater $1: 10$ ). The diluted suspension $(100 \mu \mathrm{l})$ was spread on an $\mathrm{A} 1+\mathrm{C}$ agar plate. The $\mathrm{A} 1+\mathrm{C}$ medium contained $10 \mathrm{~g}$ starch (Difco), 4 g peptone (Difco), $2 \mathrm{~g}$ yeast extract (Difco), $1 \mathrm{~g}$ calcium carbonate (Aldrich) and $18 \mathrm{~g}$ agar (Difco) in 11 filtered seawater ( $\mathrm{pH}$ 7.0). The plate was incubated for 3 weeks at $25{ }^{\circ} \mathrm{C}$ under aerobic conditions. Individual colonies were subcultured on $\mathrm{A} 1+\mathrm{C}$ agar medium before each pure bacterial strain was cultured in $\mathrm{A} 1+\mathrm{C}$ liquid medium $(25 \mathrm{ml})$ while shaking at 200 r.p.m for 7 days at $25{ }^{\circ} \mathrm{C}$. Stocks of each isolated bacterial strain were generated and stored at $-80{ }^{\circ} \mathrm{C}$ in liquid culture medium containing $20 \%(\mathrm{v} / \mathrm{v})$ glycerol.

Gram-staining was performed according to the method described by Süßmuth et al. (1987). Cultures of strain KME $001^{\mathrm{T}}$ grown at $25{ }^{\circ} \mathrm{C}$ for 5 days in $\mathrm{A} 1+\mathrm{C}$ medium were used to determine phenotypic characteristics. The ability of strain KME $001^{\mathrm{T}}$ to grow on various agar media was evaluated using marine agar (MA) (Difco), $\mathrm{A} 1+\mathrm{C}$ agar, $\mathrm{A} 1$ agar (A1 $+\mathrm{C}$ agar medium without calcium carbonate), R2A agar (Difco) and trypticase soy agar (TSA; Difco) for 5 days at $25{ }^{\circ} \mathrm{C}$. Colony morphology and cell motility were investigated using a light microscope (Eclipse Te2000-U; Nikon). Cell morphology and the presence of flagella were observed using a scanning electron microscope (SEM; S$3500 \mathrm{~N}$, Hitachi). The requirement for and tolerance of $\mathrm{NaCl}$ was examined on $\mathrm{A} 1+\mathrm{C}$ agar plates that were prepared by using artificial seawater containing different concentrations of $\mathrm{NaCl}(0-10 \%$; w/v with intervals of $1 \%)$. The ability of strain $\mathrm{KME} 001^{\mathrm{T}}$ to grow at various temperatures was examined at $4,7,10,15,20,25,30,37,42$ and $45{ }^{\circ} \mathrm{C}$ on $\mathrm{A} 1+\mathrm{C}$ agar plates. Growth at different $\mathrm{pH}$ values was evaluated using $\mathrm{A} 1+\mathrm{C}$ liquid medium for which the $\mathrm{pH}$ values were adjusted from $\mathrm{pH} 3.0$ to $\mathrm{pH} 12.0$ (at intervals of $1.0 \mathrm{pH}$ unit). Oxidase activity was examined using oxidation of $1 \% N, N, N^{\prime}, N^{\prime}$-tetramethyl-p-phenylenediamine dihydrochloride (Sigma-Aldrich). Catalase activity was determined using a $3 \%(\mathrm{v} / \mathrm{v})$ hydrogen peroxide solution.

The utilization of carbon sources was investigated using the API 50 CHE system (bioMérieux) according to the manufacturer's recommendations. API 20E and API ZYM tests (bioMérieux) were used to determine additional biochemical properties.

The diaminopimelic acid stereoisomers in the cell-wall peptidoglycan were determined by using the TLC method as described by Staneck \& Roberts (1974). The bacterial menaquinones were extracted from freeze-dried biomass by using chloroform-methanol $(2: 1, \mathrm{v} / \mathrm{v})$, and analysed by reverse-phase HPLC with a Spherisorb $5 \mu \mathrm{m}$ ODS2 $(250 \times 4.6 \mathrm{~mm})$ column as described previously (Tamaoka, 1986). The analysis of fatty acid methyl esters was carried out by GC (6890; Hewlett Packard) with an HP-1 (cross-linked methyl siloxane, $30 \mathrm{~m} \times 0.32 \mathrm{~mm} \times 0.25 \mu \mathrm{m}$ ) column using the MIDI Microbial Identification System (MIS; Microbial ID) (Miller, 1982).

Chromosomal DNA of strain KME $001^{\mathrm{T}}$ was extracted using a G-spin Genomic DNA Extraction kit (iNtRON Biotechnology, Inc.). PCR amplification of the 16S rRNA gene was performed with the universal primers $27 \mathrm{~F}$ and 1492R (Lane, 1991). The DNA sequencing reaction was carried out with an ABI Prism BigDye terminator cycle sequencing ready reaction kit v3.1 (Applied Biosystems). The sequencing product was purified using a Montage dye removal kit (Millipore) according to the manufacturer's protocol. Gene sequences were determined on a PerkinElmer capillary DNA Sequencer (model ABI 3730XL; Applied Biosystems). The 16S rRNA gene sequence of strain $\mathrm{KME} 001^{\mathrm{T}}$ was edited using the BioEdit program (Hall, 1999) and compared with primary sequence information within the GenBank/DDBJ/EMBL nucleotide sequence database using BLAST (Altschul et al., 1997). Pairwise nucleotide sequence similarity values were determined by using the EzTaxon server 2.1 (http://www. eztaxon.org/; Chun et al., 2007). Multiple alignments were performed with the CLUSTAL w program 1.83 (Thompson et al., 1994) and evolutionary distances calculated by using the Kimura two-parameter model (Kimura, 1983). The phylogenetic tree was constructed by means of the neighbour-joining method (Saitou \& Nei, 1987) with bootstrap values based on 1000 resamplings (Felsenstein, 1985 ) with the MEGA software package 4.0 (Kumar et al., 2008).

DNA-DNA hybridization was determined by the membrane filter method using the DIG High Prime DNA labelling and detection starter kit II (Roche Applied Science) according to the manufacturer's instructions. The DNA $\mathrm{G}+\mathrm{C}$ content of strain $\mathrm{KME} 001^{\mathrm{T}}$ was determined by HPLC of the P1 nuclease hydrolysate (Katayama-Fujimura et al., 1984). 
The optical rotation of the taurocholic acid was measured on a Perkin-Elmer polarimeter (model 343; Perkin-Elmer). NMR spectra were obtained in $\mathrm{CD}_{3} \mathrm{OD}$ on a Varian UNITY Plus $500 \mathrm{MHz}$ spectrometer. NMR chemical shifts were referenced to the residual solvent peaks $\left(\delta_{\mathrm{H}} 3.30\right.$ and $\delta_{\mathrm{C}} 45.3$ for $\left.\mathrm{CD}_{3} \mathrm{OD}\right)$. Low-resolution electrospray ionisation mass spectroscopy (ESI-MS) was measured on an Agilent Technologies VS/Agilent 1100 system and TLC was performed by using Merck silica gel 60 F254. Silica gel 60 (Merck, 0.063-0.200 mm) was also used for flash column chromatography. Preparative HPLC separations were performed using a Gilson 321 HPLC system with a Phenomenex Luna C18(2) $10 \mu \mathrm{m}$ column $(10 \times 250 \mathrm{~mm})$ at a flow rate of $4 \mathrm{ml} \mathrm{min}{ }^{-1}$. HPLC-MS was performed with an Agilent 1100 LC-MS system using a Phenomenex Luna C18(2) $5 \mu \mathrm{m}$ column $(4.6 \times 150 \mathrm{~mm})$ at a flow rate of $0.7 \mathrm{ml} \mathrm{min}^{-1}$. A Waters 1525 HPLC-PDA system with a Phenomenex Luna C18(2) $5 \mu \mathrm{m}$ column $(4.6 \times 150 \mathrm{~mm})$ at a flow rate of $1.0 \mathrm{ml} \mathrm{min}{ }^{-1}$ was used for the analysis of extracts and fractions.

Strain KME $001^{\mathrm{T}}$ was a Gram-positive, aerobic, non-sporeforming and non-motile bacterium on $\mathrm{A} 1+\mathrm{C}$ medium at $25^{\circ} \mathrm{C}$. SEM observations of strain KME $001^{\mathrm{T}}$ revealed rodshaped bacterial cells. Cells were $4.1-6.0 \mu \mathrm{m}$ in length and $0.4-0.5 \mu \mathrm{m}$ in diameter (Fig. 1). Colonies were circular, convex, smooth, light yellowish and $0.6-1 \mathrm{~mm}$ in diameter on $\mathrm{A} 1+\mathrm{C}$ agar plates after 5 days at $25^{\circ} \mathrm{C}$. Strain $\mathrm{KME}$ $001^{\mathrm{T}}$ grew between 10 and $42^{\circ} \mathrm{C}$, with an optimal temperature for growth of $25{ }^{\circ} \mathrm{C}$ on $\mathrm{A} 1+\mathrm{C}$ agar plates. Strain KME $001^{\mathrm{T}}$ also grew on marine agar, R2A agar and A1 agar plates at $25{ }^{\circ} \mathrm{C}$. However, no growth was observed on TSA medium. Previous studies have shown that the type strains of all recognized species of the genus Aeromicrobium are capable of growth on TSA, apart from A. panaciterrae. The phenotypic characteristics of strain KME $001^{\mathrm{T}}$ were compared with those of related species of the genus Aeromicrobium (Table 1). Interestingly, only strain KME

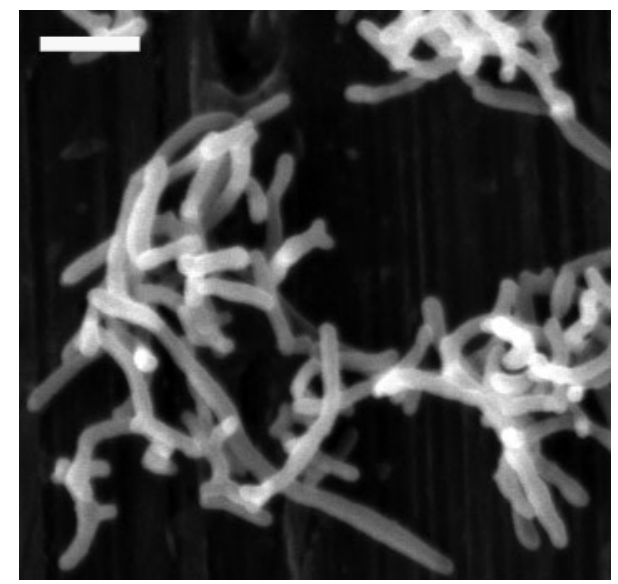

Fig. 1. Scanning electron micrograph of cells of strain $\mathrm{KME} 001^{\top}$ cultivated at $25{ }^{\circ} \mathrm{C}$ for 5 days in $\mathrm{A} 1+\mathrm{C}$ liquid medium. Bar, $2 \mu \mathrm{m}$.
$001^{\mathrm{T}}$ and the type strain of $A$. marinum were capable of using mannitol as a sole carbon source.

LL-Diaminopimelic acid was found to be the diagnostic diamino acid of the cell-wall peptidoglycan of strain KME $001^{\mathrm{T}}$. The predominant menaquinone was MK-9 $\left(\mathrm{H}_{4}\right)$. These characteristics were similar to those of other type strains of species of the genus Aeromicrobium. The predominant fatty acids of $\mathrm{KME} 001^{\mathrm{T}}(\geqslant 1.00 \%)$ were $\mathrm{C}_{18: 1} \omega 9 c \quad(35.24 \%), \mathrm{C}_{16: 0} \quad(31.50 \%), \quad 10$-methyl $\mathrm{C}_{18: 0}$ $(21.05 \%), \mathrm{C}_{18: 0}(5.47 \%), \mathrm{C}_{17: 0}(1.47 \%)$ and $\mathrm{C}_{16: 1} \omega 9 c$ $(1.71 \%)$ (see Supplementary Table S1 in IJSEM Online). The fatty acid composition of strain $\mathrm{KME} 001^{\mathrm{T}}$ was similar to those of other species of the genus Aeromicrobium. However, strain KME $001^{\mathrm{T}}$ was unique in that it lacked $\mathrm{C}_{16: 0} 2-\mathrm{OH}$, a fatty acid detected in all other recognized species of the genus Aeromicrobium.

Phylogenetic analyses using the 16S rRNA gene sequence (1358 nt) of strain KME $001^{\mathrm{T}}$ revealed that it was associated with the family Nocardioidaceae and was most closely related to members of the genus Aeromicrobium (Fig. 2). Comparisons of the 16S rRNA gene sequence of strain KME $001^{\mathrm{T}}$ with sequences from related genera, including Aeromicrobium, Marmoricola, Pimelobacter, Nocardioides and Lechevalieria, showed that strain KME $001^{\mathrm{T}}$ was most closely related to members of the genus Aeromicrobium. Strain KME $001^{\mathrm{T}}$ shared relatively high sequence similarity (96.5-97.7\%) with all other species of the genus Aeromicrobium species depicted on the phylogenetic tree (Fig. 2). The 16S rRNA gene sequence similarity values between strain $\mathrm{KME} 001^{\mathrm{T}}$ and the type strains of related Aeromicrobium species were: A. ginsengisoli (97.7\%), A. erythreum $(97.6 \%)$, A. ponti $(97.5 \%)$, A. alkaliterrae (97.4\%), A. marinum (97.4\%), A. panaciterrae (97.1\%), A. tamlense (96.5\%), A. fastidiosum (96.5\%) and A. flavum (96.2\%). Although the type strain of A. ginsengisoli appeared to have the highest gene sequence similarity with strain KME $001^{\mathrm{T}}$, it was located on another branch belonging to $A$. marinum and A. panaciterrae in the phylogenetic tree due to the higher levels of $16 \mathrm{~S}$ rRNA sequence similarity with these species, $99.3 \%$ and $99.0 \%$, respectively.

DNA-DNA hybridization was performed to evaluate the genomic DNA relatedness between strain $\mathrm{KME} 001^{\mathrm{T}}$ and its nearest neighbours, A. ginsengisoli KCTC $19207^{\mathrm{T}}$, A. erythreum KCCM $41104^{\mathrm{T}}$ and A. ponti KACC $20565^{\mathrm{T}}$. Strains with more than $70 \%$ DNA-DNA relatedness are generally assumed to be members of the same species (Wayne et al., 1987). The DNA-DNA relatedness values between strain $\mathrm{KME} 001^{\mathrm{T}}$ and $A$. ginsengisoli $\mathrm{KCTC}$ $19207^{\mathrm{T}}$, A. erythreum KCCM $41104^{\mathrm{T}}$ and A. ponti KACC $20565^{\mathrm{T}}$ were $49.6 \%, 57.1 \%$ and $63.5 \%$, respectively. The DNA G $+\mathrm{C}$ content of strain KME $001^{\mathrm{T}}$ was $75.9 \mathrm{~mol} \%$. This value appeared to be slightly higher than that found for other members of the genus Aeromicrobium, which range from 65.5 to $74.0 \mathrm{~mol} \%$.

On the basis of these phenotypic and phylogenetic data, it is proposed that strain KME $001^{\mathrm{T}}$ represents a new 
Table 1. Phenotypic characteristics of strain $\mathrm{KME} 001^{\top}$ and related species of the genus Aeromicrobium

Taxa: 1, strain KME $001^{\mathrm{T}}$ (data from this study); 2, A. ginsengisoli Gsoil 098 ${ }^{\mathrm{T}}$ (Kim et al., 2008); 3, A. erythreum NRRL B-3381 ${ }^{\mathrm{T}}$ (Miller et al., 1991; Cui et al., 2007); 4, A. ponti HSW- $1^{\mathrm{T}}$ (Lee \& Lee, 2008); 5, A. alkaliterrae KSL-107 ${ }^{\mathrm{T}}$ (Yoon et al., 2005; Kim et al., 2008); 6, A. marinum T2 ${ }^{\mathrm{T}}$ (Bruns et al., 2003; Yoon et al., 2005; Kim et al., 2008); 7, A. panaciterrae Gsoil 161 ${ }^{\mathrm{T}}$ (Cui et al., 2007); 8, A. tamlense SSW1-57 ${ }^{\mathrm{T}}$ (Lee \& Kim, 2007); 9, A. fastidiosum DSM $10552^{\mathrm{T}}$ (Collins \& Stackebrandt, 1989; Tamura \& Yokota, 1994; Yoon et al., 2005; Cui et al., 2007); 10, A. flavum TYLN1 ${ }^{\mathrm{T}}$ (Tang et al., 2008). All strains were positive for utilization of trehalose. +, Positive reaction or growth; w, weakly positive; - , negative reaction or no growth; ND, not determined.

\begin{tabular}{|c|c|c|c|c|c|c|c|c|c|c|}
\hline Characteristic & 1 & $2^{\star}$ & $3^{\star}$ & $4^{\star}$ & $5 \dagger$ & $6 \dagger$ & $7 \dagger$ & $8 \dagger$ & $9 \dagger$ & $10 \dagger$ \\
\hline Cell morphology & Rods & Cocci & $\begin{array}{l}\text { Irregular rods, } \\
\text { cocci }\end{array}$ & Rods & $\begin{array}{l}\text { Rods, } \\
\text { cocci }\end{array}$ & Rods & Rods & Irregular rods & $\begin{array}{l}\text { Rods, } \\
\text { cocci }\end{array}$ & $\begin{array}{l}\text { Irregular } \\
\text { rods }\end{array}$ \\
\hline Motility & - & - & - & - & - & - & - & - & + & - \\
\hline Temperature range $\left({ }^{\circ} \mathrm{C}\right)$ & $10-42$ & ND & $21-40$ & $4-42$ & $4-35$ & $4-35$ & $15-30$ & $10-42$ & $5-30$ & $25-37$ \\
\hline $\begin{array}{l}\text { Optimum temperature for } \\
\text { growth }\left({ }^{\circ} \mathrm{C}\right)\end{array}$ & 25 & 30 & 35 & $30-37$ & 25 & 25 & ND & 30 & 25 & 30 \\
\hline $\mathrm{pH}$ range & $5.0-10.0$ & $5.0-8.5$ & $5.0-9.0$ & $4.1-12.1$ & $6.0-11.0$ & $5.5-9.5$ & $5.0-8.5$ & $5.1-10.1$ & $5.0-8.0$ & $5.0-10.0$ \\
\hline Oxidase & - & + & + & - & - & - & - & - & + & + \\
\hline Catalase & + & - & + & + & + & + & - & + & + & + \\
\hline Urease & - & - & - & - & - & $-\ddagger$ & - & - & - & $\mathrm{W}$ \\
\hline \multicolumn{11}{|l|}{ Utilization of: } \\
\hline Acetate & + & + & + & + & - & $+\ddagger$ & + & + & + & ND \\
\hline L-Arabinose & + & + & + & + & + & - & - & - & + & - \\
\hline Citrate & - & - & ND & + & - & - & - & - & + & ND \\
\hline D-Fructose & + & + & + & + & - & - & - & + & + & + \\
\hline D-Glucose & + & + & + & + & + & - & + & + & + & + \\
\hline D-Mannose & + & + & - & + & - & - & + & + & + & - \\
\hline Mannitol & + & - & - & - & $w \$$ & + & - & - & - & ND \\
\hline Maltose & + & + & - & + & + & - & + & + & - & + \\
\hline Rhamnose & - & + & - & - & $+\S$ & - & - & - & - & - \\
\hline Salicin & - & - & - & $\mathrm{W}$ & + & - & + & - & - & - \\
\hline Sucrose & + & + & + & + & + & - & + & + & + & + \\
\hline D-Xylose & + & + & + & + & - & - & - & - & + & - \\
\hline \multicolumn{11}{|l|}{ Enzyme activities (API ZYM): } \\
\hline Acid phosphatase & - & + & + & + & + & - & + & + & + & - \\
\hline Alkaline phosphatase & - & - & + & + & - & - & + & + & + & - \\
\hline Esterase (C4) & + & + & $\mathrm{w}$ & + & + & + & w & - & + & + \\
\hline$\alpha$-Glucosidase & $\mathrm{W}$ & + & + & + & + & - & - & + & + & + \\
\hline $\begin{array}{l}\text { Naphthol-AS-BI- } \\
\text { phosphohydrolase }\end{array}$ & $\mathrm{W}$ & + & - & - & + & $\mathrm{w}$ & + & $\mathrm{w}$ & $\mathrm{w}$ & - \\
\hline Trypsin & - & - & $\mathrm{W}$ & - & - & - & - & $\mathrm{W}$ & - & - \\
\hline DNA G $+\mathrm{C}$ content $(\mathrm{mol} \%)$ & 75.9 & 66.8 & $71-73$ & 74.0 & 71.5 & 70.6 & 65.5 & 72.7 & $71-72$ & 73.3 \\
\hline
\end{tabular}

${ }^{\star}$ The results of API ZYM tests for taxa 2, 3 and 4 were derived from our experiments, while other data were from previously reported literature (Kim et al., 2008; Miller et al., 1991; Cui et al., 2007; Lee \& Lee, 2008).

$\dagger$ All data were from the above-mentioned literature for each type strain.

¥Data from Kim et al. (2008). The API ZYM data for taxon 6 were from Yoon et al. (2005). Other data in the same column were from Bruns et al. (2003).

$\S$ Data from Kim et al. (2008). Other data in the same column were from Yoon et al. (2005).

member of the genus Aeromicrobium. The name Aeromicrobium halocynthiae sp. nov. is proposed.

In order to investigate secondary metabolite production by strain $\mathrm{KME} 001^{\mathrm{T}}$, the strain was cultured in ten 11 Erlenmeyer flasks each containing $500 \mathrm{ml} \mathrm{A} 1+\mathrm{C}$ broth. The flasks were incubated at $25{ }^{\circ} \mathrm{C}$ for 7 days with shaking at 200 r.p.m. Secondary metabolites in the culture broth were analysed every day (from days 3-7) by using an Agilent 1100 LC-MS system using a Phenomenex Luna $5 \mu \mathrm{m}$ C-18(2) analytical column $(4.6 \times 150 \mathrm{~mm})$ (see Supplementary Fig. S1 in IJSEM Online). At the end of the culture period (day 7), $20 \mathrm{~g} \mathrm{l}^{-1}$ Amberlite XAD-7 adsorbent resin was added to each flask, followed by 


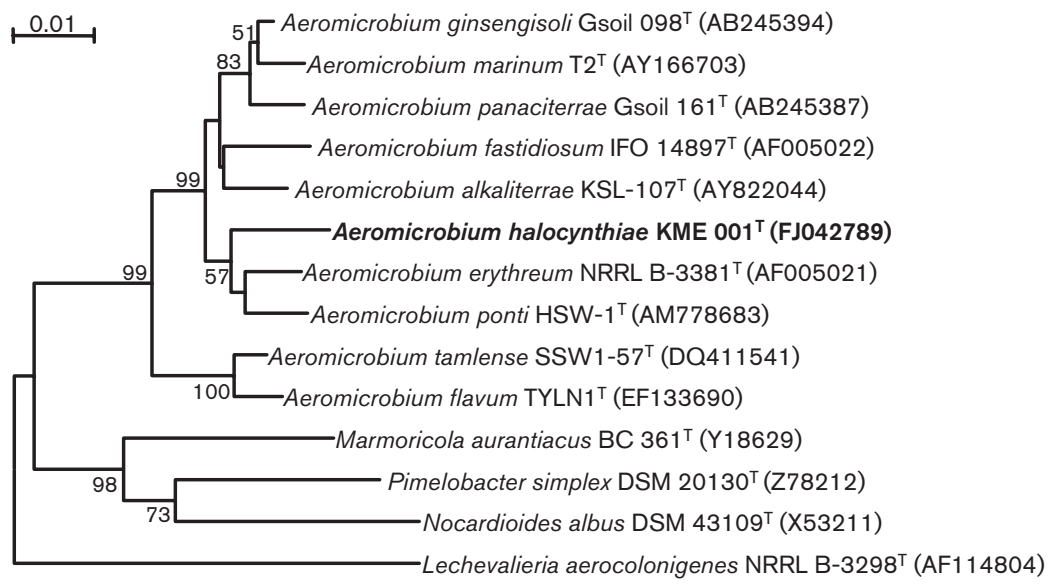

Fig. 2. Neighbour-joining tree based on $16 \mathrm{~S}$ rRNA gene sequences showing the phylogenetic position of strain $\mathrm{KME} 001^{\top}$, recognized species of the genus Aeromicrobium and some species of related taxa. Bootstrap values (>50\%) obtained with 1000 resamplings are given at the branch-points. Bar, 0.01 substitutions per nucleotide position.

shaking for two additional hours. The resin was then collected by filtration through cheesecloth, washed with deionized water and eluted twice with acetone. The acetone solution was concentrated under reduced pressure to yield $1.2 \mathrm{~g}$ crude extract. The acetone extract was fractionated using silica gel flash column chromatography and a step gradient elution with methylene chloride and methanol (20:1, 10:1, $3: 1$ and methanol) to give four subfractions. The $100 \%$ methanol fraction $(374 \mathrm{mg}$ ) was dried in vacuo and fractionated by reverse-phase HPLC using an isocratic elution of $23 \%$ acetonitrile in water [flow rate $4 \mathrm{ml} \mathrm{min}^{-1}$, Phenomenex Luna C18(2) $10 \mu \mathrm{m} 10 \times 250 \mathrm{~mm}$. Taurocholic acid ( $3 \mathrm{mg}$ ) was purified by repeated HPLC in the same manner as the $100 \%$ methanol fraction. Taurocholic acid was obtained as an optically active, pale yellowish powder. The structure of the taurocholic acid was characterized by comparing the physicochemical properties and spectroscopic data (see Supplementary Figs S2 and S3) with values previously reported in the literature (Gowda et al., 2006; Ijare et al., 2005). Cholic acid is synthesized from cholesterol in the mammalian liver. To determine whether cholesterol, the precursor of many cholic acids, was present in the $\mathrm{A} 1+\mathrm{C}$ liquid medium used to cultivate strain $\mathrm{KME} 001^{\mathrm{T}}$, TLC analysis of the $\mathrm{A} 1+\mathrm{C}$ liquid medium alone were performed and compared with authentic cholesterol (see Supplementary Figure S4). No cholesterol was detected in the medium, suggesting that strain KME $001^{\mathrm{T}}$ was capable of producing taurocholic acid de novo. To the authors' knowledge, strain $\mathrm{KME} 001^{\mathrm{T}}$ is the first example of a taurocholic acid-producing bacterium.

\section{Description of Aeromicrobium halocynthiae sp. nov.}

Aeromicrobium halocynthiae (ha.lo.cyn'thi.ae. N.L. gen. n. halocynthiae of Halocynthia roretzi, the ascidian from which the type strain was isolated).

Cells are Gram-positive, aerobic, non-spore-forming, rodshaped and non-motile. Cells are approximately 0.4$0.5 \mu \mathrm{m}$ in diameter and $4.1-6.0 \mu \mathrm{m}$ in length. When grown on $\mathrm{A} 1+\mathrm{C}$ agar plates at $25{ }^{\circ} \mathrm{C}$ for 5 days, colonies are circular, convex, smooth, light yellowish and 0.6-1 mm in diameter. Growth is observed at $10-42{ }^{\circ} \mathrm{C}$, with optimal growth at $25{ }^{\circ} \mathrm{C}$. Growth occurs at $\mathrm{pH} 5-10$. Grows in culture media containing $0-6 \%(\mathrm{w} / \mathrm{v}) \mathrm{NaCl}$. No growth on TSA medium. Oxidase-negative and catalase-positive. Produces acetoin and oxidizes arabinose. Does not utilize citrate, does not produce $\mathrm{H}_{2} \mathrm{~S}$ or indole and does not oxidize glucose, mannitol, inositol, sorbitol, rhamnose, sucrose, melibiose or amygdalin. The following carbon sources are utilized: acetate, glycerol, L-arabinose, ribose, D-xylose, D-glucose, D-fructose, D-mannose, inositol, mannitol, maltose, sucrose, trehalose, turanose, D-tagatose and 5-ketogluconate. Erythritol, D-arabinose, L-xylose, adonitol, methyl $\beta$-xyloside, galactose, L-sorbose, rhamnose, dulcitol, sorbitol, methyl $\alpha$-D-mannoside, methyl $\alpha$-Dglucoside, $N$-acetylglucosamine, amygdalin, arbutin, aesculin, salicin, cellobiose, lactose, melibiose, inulin, melezitose, raffinose, starch, glycogen, xylitol, $\beta$-gentiobiose, D-lyxose, D-fucose, L-fucose, D-arabitol, L-arabitol, gluconate and 2-ketogluconate are not utilized as sole carbon and energy sources. With API ZYM and API 20E systems, esterase (C4), esterase lipase (C8) and leucine arylamidase activities are detected. $\alpha$-Glucosidase, naphthol-AS-BI-phosphohydrolase and valine arylamidase are weakly active. The following enzyme activities are not detected: alkaline phosphatase, lipase (C14), cystine arylamidase, trypsin, acid phosphatase, $\alpha$-chymotrypsin, $\alpha$-galactosidase, $\beta$-galactosidase, $\beta$-glucuronidase, $\beta$-glucosidase, $N$-acetyl- $\beta$-glucosaminidase, $\alpha$-mannosidase, $\alpha$ fucosidase, arginine dihydrolase, lysine decarboxylase, ornithine decarboxylase, urease, tryptophan deaminase, cytochrome-oxidase and gelatinase. LL-Diaminopimelic acid is the diagnostic diamino acid of the cell-wall peptidoglycan. The predominant menaquinone is MK$9\left(\mathrm{H}_{4}\right)$. The major fatty acids are $\mathrm{C}_{18: 1} \omega 9 c, \mathrm{C}_{16: 0}$ and 10methyl $\mathrm{C}_{18: 0}$. The type strain produces taurocholic acid, a bile acid, as a major secondary metabolite.

The type strain, KME $001^{\mathrm{T}} \quad\left(=\mathrm{JCM} \quad 15749^{\mathrm{T}}=\mathrm{KCCM}\right.$ $\left.90079^{\mathrm{T}}\right)$, was isolated from a marine ascidian, Halocynthia roretzi, collected off the coast of Gangneung, 
Korea. The DNA $\mathrm{G}+\mathrm{C}$ content of the type strain is $75.89 \mathrm{~mol} \%$.

\section{Acknowledgements}

This work was supported by KIST institutional program (2Z03270), and the National Fisheries Research and Development Institute (RP2010-BT-022), Republic of Korea. We thank Dr Erin A. Gontang, Harvard Medical School, for scientific advice and English revision.

\section{References}

Altschul, S. F., Madden, T. L., Schaffer, A. A., Zhang, J., Zhang, Z., Miller, W. \& Lipman, D. J. (1997). Gapped BLAST and PSI-BLAST: a new generation of protein database search programs. Nucleic Acids Res 25, 3389-3402.

Bruns, A., Philipp, H., Cypionka, H. \& Brinkhoff, T. (2003). Aeromicrobium marinum sp. nov., an abundant pelagic bacterium isolated from the German Wadden Sea. Int J Syst Evol Microbiol 53, 1917-1923.

Chun, J., Lee, J.-H., Jung, Y., Kim, M., Kim, S., Kim, B. K. \& Lim, Y. W. (2007). EzTaxon: a web-based tool for the identification of prokaryotes based on $16 \mathrm{~S}$ ribosomal RNA gene sequences. Int J Syst Evol Microbiol 57, 2259-2261.

Collins, M. D. \& Stackebrandt, E. (1989). Molecular taxonomic studies on some LL-diaminopimelic acid-containing coryneforms from herbage: description of Nocardioides fastidiosa sp. nov. FEMS Microbiol Lett 48, 289-293.

Cui, Y. S., Im, W. T., Yin, C. R., Lee, J. S., Lee, K. C. \& Lee, S. T. (2007). Aeromicrobium panaciterrae sp. nov., isolated from soil of a ginseng field in South Korea. Int J Syst Evol Microbiol 57, 687-691.

Dewick, P. M. (2001). Medicinal natural products: a biosynthetic approach. In The Mevalonate and Deoxyxylulose Phosphate Pathways: Terpenoids and Steroids, 2nd edn., pp. 260-262. West Sussex, UK: Wiley.

Felsenstein, J. (1985). Confidence limits on phylogenies: an approach using the bootstrap. Evolution 39, 783-791.

Gowda, N. G. A., ljare, O. B., Somashekar, B. S., Sharma, A., Kapoor, V. K. \& Khetrapal, C. L. (2006). Single-step analysis of individual conjugated bile acids in human bile using ${ }^{1} \mathrm{H}$ NMR spectroscopy. Lipids 41, 591-603.

Hall, T. A. (1999). BioEdit: a user-friendly biological sequence alignment editor and analysis program for Windows 95/98/NT. Nucleic Acids Symp Ser 41, 95-98.

ljare, O. B., Somashekar, B. S., Jadegoud, Y. \& Gowda, N. G. A. (2005). ${ }^{1} \mathrm{H}$ and ${ }^{13} \mathrm{C}$ NMR characterization and stereochemical assignments of bile acids in aqueous media. Lipids 40, 1031-1041.

Katayama-Fujimura, Y., Komatsu, Y., Kuraishi, H. \& Kaneko, T. (1984). Estimation of DNA base composition by high performance liquid chromatography of its nuclease P1 hydrolysate. Agric Biol Chem 48, 3169-3172.

Kim, D., Lee, J. S., Kim, J., Kang, S.-J., Yoon, J.-H., Kim, W. G. \& Lee, C. H. (2007). Biosynthesis of bile acids in a variety of marine bacterial taxa. J Microbiol Biotechnol 17, 403-407.

Kim, M. K., Park, M.-J., Im, W.-T. \& Yang, D.-C. (2008). Aeromicrobium ginsengisoli sp. nov., isolated from a ginseng field. Int J Syst Evol Microbiol 58, 2025-2030.
Kimura, M. (1983). The Neutral Theory of Molecular Evolution. Cambridge: Cambridge University Press.

Kumar, S., Nei, M., Dudley, J. \& Tamura, K. (2008). MEGA: a biologistcentric software for evolutionary analysis of DNA and protein sequences. Brief Bioinform 9, 299-306.

Lane, D. J. (1991). 16S/23S rRNA sequencing. In Nucleic Acid Techniques in Bacterial Systematics, pp. 115-175. Edited by E. Stackebrandt \& M. Goodfellow. Chichester: Wiley.

Lee, S. D. \& Kim, S. J. (2007). Aeromicrobium tamlense sp. nov., isolated from dried seaweed. Int J Syst Evol Microbiol 57, 337341.

Lee, D. W. \& Lee, S. D. (2008). Aeromicrobium ponti sp. nov., isolated from seawater. Int J Syst Evol Microbiol 58, 987-991.

Maneerat, S., Nitoda, T., Kanzaki, H. \& Kawai, F. (2005). Bile acids are new products of a marine bacterium, Myroides sp. strain SM1. Appl Microbiol Biotechnol 67, 679-683.

Miller, L. T. (1982). Single derivatization method for routine analysis of bacterial whole-cell fatty acid methyl esters, including hydroxy acids. J Clin Microbiol 16, 584-586.

Miller, E. S., Woese, C. R. \& Brenner, S. (1991). Description of the erythromycin-producing bacterium Arthrobacter sp. strain NRRL B3381 as Aeromicrobium erythreum gen. nov., sp. nov. Int J Syst Bacteriol 41, 363-368.

Park, S.-C., Kim, C.-J., Uramoto, M., Yun, H. I., Yoon, K.-H. \& Oh, T.-K. (1995). Antibacterial substance produced by Streptococcus faecium under anaerobic culture. Biosci Biotechnol Biochem 59, 1966-1967.

Saitou, N. \& Nei, M. (1987). The neighbor-joining method: a new method for reconstructing phylogenetic trees. Mol Biol Evol 4, 406425.

Staneck, J. L. \& Roberts, G. D. (1974). Simplified approach to identification of aerobic actinomycetes by thin-layer chromatography. Appl Microbiol 28, 226-231.

Süßmuth, R., Eberspächer, J., Haag, R. \& Springer, W. (1987). Biolchemischmikrobiologisches Praktikum. Stuttgart: Thieme Verlag.

Tamaoka, J. (1986). Analysis of bacterial menaquinone mixtures by reverse-phase high-performance liquid chromatography. Methods Enzymol 123, 251-256.

Tamura, T. \& Yokota, A. (1994). Transfer of Nocardioides fastidiosa Collins and Stackebrandt 1989 to the genus Aeromicrobium as Aeromicrobium fastidiosum comb. nov. Int J Syst Bacteriol 44, 608611.

Tang, Y., Zhou, G., Zhang, L., Mao, J., Luo, X., Wang, M. \& Fang, C. (2008). Aeromicrobium flavum sp. nov., isolated from air. Int J Syst Evol Microbiol 58, 1860-1863.

Thompson, J. D., Higgins, D. G. \& Gibson, T. J. (1994). CLUSTAL W: Improving the sensitivity of progressive multiple sequence alignment through sequence weighting, position specific gap penalties and weight matrix choice. Nucleic Acids Res 22, 4673-4680.

Wayne, L. G., Brenner, D. J., Colwell, R. R., Grimont, P. A. D., Kandler, O., Krichevsky, M. I., Moore, L. H., Moore, W. E. C., Murray, R. G. E. \& other authors (1987). International Committee on Systematic Bacteriology. Report of the ad hoc committee on reconciliation of approaches to bacterial systematics. Int J Syst Bacteriol 37, 463-464.

Yoon, J.-H., Lee, C.-H. \& Oh, T. K. (2005). Aeromicrobium alkaliterrae sp. nov., isolated from an alkaline soil, and emended description of the genus Aeromicrobium. Int J Syst Evol Microbiol 55, 2171-2175. 